\title{
The Status of the Wissenschaftslehre: Transcendental and Ontological Grounds in Fichte
}

\author{
Sebastian Gardner
}

\begin{abstract}
In this paper I pursue the question whether transcendental explanation in Fichte's Wissenschaftslehre should be regarded as ontologically committed. It is natural to assume that transcendental explanation in the Wissenschaftslehre should be construed non-ontologically: Schulze's criticisms of Kantian philosophy and Jacobi's objection to philosophical justification supply Fichte with motives for freeing transcendental explanation of ontological commitment. However, the situation is not, I argue, clear-cut: Fichte's explicit remarks are equivocal and exhibit tensions, and interpretations of the WL which imply its non-ontological status are open to criticism. Finally I suggest a way in which Fichte's position on the WL's status may be regarded as coherent and defensible, and indicate how the relation of Fichte to Schelling and Hegel may be understood in its light.
\end{abstract}

\section{Inverting the form of philosophical explanation}

A firm majority of commentators would reject the suggestion that the German idealists offer metaphysical explanations of the same order as those offered by, say, the rationalists. On the contrary, the notion that, whatever continuities there may be, there is a deep difference of status between German idealist metaphysics and traditional, pre-Kantian metaphysics, is a commonplace. Equally commonplace is the thought that the German idealists were engaged in attempting to define and employ a new form of philosophical explanation, which does not consist simply in a reapplication without alteration of the philosophical methods showcased in the first Critique. A third notion often encountered is that what the German idealists were aiming to do was not to affirm or postulate another world different from and additional to this one, but to redescribe this world: they were attempting "to articulate an alternative vision of reality - and not a vision of some alternative reality."

These claims are brought together in the idea that the German idealists, in furnishing their redescriptions of this world, invert the form of philosophical explanation employed in common sense and pre-Copernican philosophy, with the result that, from the ordinary or the pre-Kantian standpoint, the explanation they offer for this world appears to be an image of it in inverted form. ${ }^{2}$ The German idealists themselves employ the idea of inverting common sense. Fichte declares that he is "concerned with the complete reversal [die völlige Umkehrung]" of ordinary and preKantian ways of thinking, ${ }^{3}$ for which reason the Wissenschaftslehre is necessarily understood from the ordinary standpoint as saying the opposite of what it in fact

\footnotetext{
${ }^{1}$ Bell, 2001, p. 177. Bell describes this as "the goal of a transcendental theory" in general, not only of German idealism.

${ }^{2}$ See, e.g., Kuehn, 1987, pp. 11-12.

${ }^{3}$ Fichte, 1797a, p. 5 [FW I, 421].
} 
says. ${ }^{4}$ Similarly, Schelling says that "transcendental idealism arises in general through the direct inversion [die gerade Umkehrung] of previous modes of philosophical explanation." "And the aim of world-inversion is affirmed explicitly by Schelling and Hegel in their Introduction to the Kritisches Journal:

[philosophy] only is philosophy in virtue of being directly opposed to the understanding and hence even more opposed to healthy common sense, under which label we understand the limitedness in space and time of a race of men; in its relationship to common sense the world of philosophy is in and for itself an inverted world [eine verkehrte Welt]. ${ }^{6}$

My aim here is to examine a dimension of German idealism which is not often highlighted as such, namely the way in which German idealism breaks with the understanding of the relation between explanation and ontology found in common sense and traditional metaphysics. The question of the ontological status of the grounds adduced in philosophical explanation is, I will try to show, a central, abiding issue in the German idealists' formulation of their positions and in the arguments between them, and the positions which the German idealists take up in their attempt to solve the deep problem which, they correctly see, surrounds this question, are part of what makes German idealist thinking difficult to grasp from, and apparently opposed to, the standpoint of common sense. Limitations of space make it impossible to discuss more than the earlier part of the story - Fichte's wrestling with the problem of ontological status - but I will indicate at the end how the issue extends beyond Fichte to Schelling and Hegel.

\section{Ontological and Non-Ontological conceptions of philosophical explanation}

As a framework for the discussion, I will employ a distinction between two rival conceptions of the source and form of philosophical explanation, the Ontological and the Non-Ontological, which are to be understand in the following terms. ${ }^{7}$

On the conception which is most natural to us, explanation is an ontological matter: to explain something is, very roughly, to link up one part of reality in the appropriate way with another part. Correspondingly, the Ontological conception of philosophical explanation holds that philosophical explanation must of necessity terminate in a claim with ontological force, and that the explanatory force of a philosophical proposition derives from the piece of reality which it discloses. On this conception, therefore, what it is to account philosophically for something is to track

\footnotetext{
${ }^{4}$ E.g. Fichte, 1797b, p. 86 [FW I, 500-1], where Fichte says that the WL's assertion that one cannot abstract from the I appears from the standpoint of ordinary consciousness to mean that "we never entertain any representation but that of ourselves." See also Fichte, 1801, pp. 85-7 [FW II, 382-4], and 1806, pp. 367-8.

${ }^{5}$ Schelling, 1800, p. 168 (translation modified) [SW II, 548].

${ }^{6}$ Hegel and Schelling, 1802, p. 283 [SW III, 521; HW II, 182].

${ }^{7}$ On this distinction, see Sacks, 2000, esp. chs. 6 and 9. My understanding of the issue is indebted heavily to this work and to Sacks' earlier 1989.
} 
relations obtaining between grounded (consequential, derivative, etc.) and grounding (antecedent, basic, etc.) items among or features of what exists.

The opposing, Non-Ontological conception of philosophical explanation affirms the proper distinctness of philosophical explanation and ontological assertion, maintaining that the explanatory force of philosophical claims should not be identified with the matter of something's having being. While this leaves open how in positive terms philosophical explanation should be conceived, in the post-Kantian transcendental context, the intelligibility of Non-Ontological explanation is bound up with the concept of perspective, understood in a special philosophical sense. Perspective in the transcendental sense is adduced as the ground of there being a domain of objects for a subject: perspective is what delivers and forms objects, and objects are "marked" by perspective in the sense that they refer back to it as the condition under which they are given, perspective itself being nothing more than an object-grounding, form-bestowing function, which could not be discharged if perspective were given in the same way as the objects that it grounds. ${ }^{8}$ The transcendental concept of perspective, on the Non-Ontological conception, differs from the ordinary concept of an individual's subjective, first-person point of view, in so far as perspective is prised apart from the ontological facts on which ordinary consciousness regards points of view as supervening. These facts include the existence of a subject whose constitution would, on ordinary, Ontological ways of thinking, be held to provide the explanation of perspective. In this way perspective becomes autonomous: because the ontological domain is internal to perspective, perspective itself is without ontological status - no ontological hinterland lies behind our backs. What philosophy does therefore, on this conception, is to give us in discursive form the perspective within which the existing world appears: the relation between the perspective, and the world given in it, is a relation of explanation or grounding; the existing world is the explanandum, perspective the explanans; final philosophical explanation, and the articulation of perspective, are one and the same. From the standpoint of common sense, the Non-Ontological conception appears as a dizzying attempt to ground the real on the unreal, quite deserving the description of an "inversion" of reality.

The commitment of a philosophical position to either an Ontological or a Non-Ontological conception of philosophical explanation, it should be noted, is distinct from its commitment to either idealism or realism, in so far as the (metaphilosophical) question of the (ontological or non-ontological) status of the grounds of philosophical explanation is different from the (metaphysical) question of the (ideal or real) status of the objects of cognition. ${ }^{9}$

\footnotetext{
${ }^{8}$ See the helpful remarks on the concept of point of view in Moore, 1997, pp. 6-14.

${ }^{9}$ Which is not to deny the obvious affinity between Non-Ontological explanation and transcendental idealism; the Non-Ontological metaphilosophical view is furthermore one candidate for an identification of the true meaning of transcendental idealism. But whether this identification - and the converse identification of Ontological explanation with transcendental realism - goes through, depends on how things develop: on how transcendental idealism is interpreted, on whether "perspective" is understood as necessarily just the perspective of a subject, and so on. As I have drawn the distinction, the Non-Ontological conception is logically compatible with the claim that the objects of cognition are (in at least some sense of the term) transcendentally real.
} 
This is not the place to consider the logic of these two positions on their own account. Yet, to anticipate some of what will emerge later, it is not hard to see what sort of dialectic results when these two conceptions of philosophical explanation confront one another in the post-Kantian context, and even how they may come to be regarded as forming a kind of antinomy. The Non-Ontological conception will meet the objection that, if perspective is adduced as the ultimate term of philosophical explanation, then some sort of ontological status must be attributed to it, if only implicitly, without which philosophical explanation will have merely subjective status and the perspective it articulates will amount to nothing more than a mere unanchored representation; while to the Ontological conception it will be objected that, to take the mere fact of the existence of anything, whatever it may be, as itself explanatory, apart from and outside a framework which allows us to understand ontological facts as explanatory and so which must itself have pre-ontological grounding status, is to collapse transcendental back into pre-transcendental explanation, and to reinstitute the skeptical gap which transcendental philosophy was meant to close, between facts of existence and our claims to knowledge of them.

\section{The background to Fichte: Kant, Schulze, Jacobi}

The notion that Fichte, in radicalising Kant and shifting Critical philosophy onto a practical basis, frees transcendental explanation of ontological commitment, obviously has much to recommend it, and it corresponds to the view of a number of commentators; ${ }^{10}$ the contrast of Fichte with Schelling, viewed as re-ontologising that which Fichte had de-ontologised, is often drawn in these terms. In this section I want to consider how the issue of the ontological commitment of philosophical explanation came to present itself to Fichte, and how Fichte's understanding of the post-Kantian context furnished him with motives for taking the Non-Ontological turn.

1. Kant. There are several respects in which the ontological commitment of Kant's philosophical claims appears uncertain, both of which came to the fore in early Kant reception and impressed themselves on Fichte.

(i) The first, clear locus of uncertainty is the transcendental theory of experience in Kant's theoretical philosophy. In connection with the wholly general problem concerning the thing in itself as ground of appearance, uncertainty concerning ontological commitment arises with respect to the subject adduced in transcendental explanation. There is a distinction to be drawn between (1) transcendental conditions in the logical sense, expressed by the relevant principles of possible experience, propositions asserting the necessity that objects be given and thought in certain ways (as in space, causally ordered, etc.); and (2) the intrasubjective ontological structures on which, it may be thought, these conditions supervene and which provide the source of the agency of their realisation in experience, these structures being what is spoken of in Kant's language of faculties or underpins Kant's faculty explanations. The much disputed exegetical question here,

\footnotetext{
${ }^{10}$ In addition to those discussed below in section 5, see di Giovanni, 2005, pp. 27-8 and 284-5, and W. Martin, 1997, e.g., pp. 12-15.
} 
of course, concerns Kant's commitment or lack of it to transcendental psychology or, it is better to say, the Ontological or Non-Ontological interpretation thereof. ${ }^{11}$ And this issue is bound up with a broader issue, concerning the scope remaining to Kant for existential assertion outside the bounds of possible experience: the one view being that the Transcendental Analytic eliminates, the other that it preserves (through the unschematised form of the categories of pure understanding) the thinkability of actual existence beyond the bounds of sensibility. ${ }^{12}$ The root of the tension lies in the fact that, on the one hand, Kant may be held to show that what it is for something to have or be known to have being is for it to stand under transcendental conditions, entailing that knowledge of transcendental conditions cannot be knowledge of anything that has existence. On the other hand, to the extent that Kant affirms an unknowable but necessarily thought realm of existing and grounding things in themselves, transcendental conditions may be thought of as ontologically grounded, and completeness of explanation appears to demand that we do so.

Now in the present context all that need be said is that it is plausible to regard Kant as intending to remain agnostic regarding the ontological underpinnings of transcendental conditions on the side of the subject, and consequently as not committing himself decisively either to an Ontological or to a Non-Ontological conception of philosophical explanation, a position which the relatively circumscribed or modest character of his philosophical project allows him to maintain: characterisation of the transcendental can remain relational and functional in Kant, its ontological status undetermined, because it is not taken as a foundation from which knowledge at the empirical level is to be derived.

(ii) The second, to us less obvious but for Fichte and his contemporaries no less important, locus of ontological uncertainty in Kant surrounds his account of the "practical cognition" of God achieved through the postulates of pure practical reason. Depending on how one understands Kant's ascription of objective reality from the practical point of view, the moral theology either reveals in pure practical reason a power of sheer cognitive insight into supersensible reality, or it collapses the very semantics of religious discourse into the terms of finite human autonomy. The profound ambiguity of this part of Kant's system is reflected in the fact that his moral theology could both be received as a new foundation for Christian doctrine, as it was by the theologians at Tübingen of whom Schelling complained in acid terms to Hegel, and be taken, as it was by Friedrich Karl Forberg, as a general blueprint for metaphysical fictionalism (of the sort we now associate with Hans Vaihinger's as-if philosophy). ${ }^{13}$ This instance of Kantian ambiguity allows itself to be explained in the same way as that which attaches to transcendental conditions: Kant's view is, plausibly, that we do not need to know, for the purpose of orientating our reason towards religious ideas, whether their proper interpretation is Ontological or not.

\footnotetext{
${ }^{11}$ Beiser, 2002, bk. I, ch. 9, sets out the issue clearly; see esp. pp. $174 \mathrm{ff}$.

12 This issue is well put in G. Martin, 1968, pp. 270-4, 278. (Martin suggests analogical conceptapplication, in addition to the un-/schematised distinction, as a way for Kant to account for his position.)

${ }^{13}$ See Forberg, 1798.
} 
The two loci of uncertainty are connected. The question of whether or not philosophical explanation must have an ontological terminus was precisely what Kant took to be at issue in his pre-Critical The Only Possible Basis for a Proof of the Existence of God (Beweisgrund), where he does affirm that sheer possibility must have an ontological ground - a conclusion which is reversed in the first Critique at the point where Kant declares that the Ideal of Pure Reason, the idea of a highest being that provides for the "sum-total of all possibilities," can be taken by us only as an idea. ${ }^{14}$ Thus, if one thinks that genuine ontologically significant cognition $i s$ achieved through the practical postulates, then Kant's Critical system may be viewed as having finally in its practical part rejoined the ontological order, of things in themselves, which transcendental explanation initially cut itself loose from. If, on the other hand, the practical cognition spoken of in connection with the practical postulates is not taken realistically, then this is not the result, and Kant's system continues to allow itself to be read as ontologically agnostic.

2. Schulze. Gottlob Ernst Schulze, as one of the many early critics of Kantianism, is of especial importance in relation to Fichte, whose review of Schulze's Aenesidemus shows how seriously he took Schulze's criticisms, and who declared that grasping the questions that Schulze had posed is a condition for understanding the WL. ${ }^{15}$

Schulze put pressure on Kant at precisely the two points just mentioned, where Kant's stand on the ontological commitment of the Critical system is uncertain, and he did so on one and the same basis. First, Schulze argues that Critical philosophy - more conspicuously in Reinhold, who has magnified certain feature of Kant, but also in Kant himself - makes appeal in its explication of objective experience to ontological items (things in themselves in general, and in particular the elements that compose what is called in Reinhold "the Faculty of Representation"), in violation of what he takes to be the defining Critical tenet, that there is no valid inference from necessities of representation to real existences. ${ }^{16}$ Second, Schulze argues that Kant's attempt to supply belief in God with a moral warrant is abortive, because the practical act of taking on this belief can be performed only if its conditions of possible success are known to be met: that is, according to Schulze, only if theoretical reason has already established that the belief has a really existing object; so Kant, in running from the practical necessity of thought to a real existence, is once again violating the ground-rule of Critical method. ${ }^{17}$

Fichte's response to Schulze appears to consist in at the very least a scaling down, perhaps a relinquishing altogether, of ontological commitment. Schulze's objections, Fichte observes, reflect his assumption that the ego must have validity "in

\footnotetext{
${ }^{14}$ A577-83/B605-611.

${ }^{15}$ Fichte GA II, 3: 389, Z. 1-4.

16 Schulze, 1792, p. 132 (Eng. trans., p. 113): "For the Critique claims that the original determinations of the human mind are the real ground or source of the necessary synthetic judgements found in our knowledge; but it does this by inferring, from the fact that we can only think of the faculty of representation as the ground of these judgements, that the mind must be their ground in actual fact too."

17 Schulze, 1792, Fünfter Brief, pp. 318-36.
} 
itself," whereas in fact its principles should hold only "for the ego itself:" 18 what we should say is that " $[\mathrm{t}]$ he faculty of representation exists for the faculty of representation and through the faculty of representation", 19 a statement which allows itself to be read as an epistemologisation of the faculty, removing it from the province of ontological commitment.

Regarding the moral theology, Schulze's claim is that the "ought" in "I ought to believe in God" is valid only if I have theoretical knowledge that it is possible for me to so believe. But, Fichte supposes, this forgets, or misunderstands, the primacy of the practical which is also part of Kant's Copernican revolution, and which makes "ought" the determinant of "can," subordinating questions of ontology. When it is appreciated, Fichte argues, that the command to believe is the direct expression of a striving which in turn derives from the self-positing of the I, we see that belief in God just $i$ a certain way of representing the object of our striving. ${ }^{20}$ The logic of Schulze's criticisms, Fichte appears to affirm, is that transcendental philosophy must lose its ontological sub-structure.

These moves are made, of course, not for the sake of saving Kant's system in its original lettering, but with a more ambitious Kantianism, shaped by Reinhold, in view, and it is not hard to see why, given this new aim, Fichte should be expected to address and resolve the matter concerning ontology and philosophical explanation that Kant had left undecided: Fichte's "absolutisation" of the transcendental, its assumption of a strongly foundational role, together with his aim of achieving a total unification of reason, make it unfeasible to persevere in Kantian agnosticism. With Fichte's appreciation of Schulze's skeptical objections factored in, Fichte is provided with very strong motivation for resolving Kant's ambiguity in a Non-Ontological direction.

3. Jacobi. One further stimulus to Fichte bearing on the issue of ontological commitment comes from Jacobi, whose philosophical concerns, as much as those of Schulze, were internalised by Fichte.

What might be expected, given Jacobi's thesis of the primitive, unanalysable and foundational role of existential awareness, and his complaint of the ontological nihilism of Kant's transcendental idealism, is an impetus to correct the alleged ontological deficit in Critical philosophy. I suggest that in a sense this does happen in Fichte, but in an indirect and complicated way, that reflects Fichte's appreciation of another strand in Jacobi's critique of philosophy.

In addition to attacking philosophy for failing to supply valid proofs justifying our ordinary beliefs, and for trading in mere empty thought-forms, Jacobi argues that the very attempt at philosophical justification of ordinary consciousness is selfstultifying. The justification that philosophy aims to provide for beliefs belonging to ordinary consciousness must be unavailable, in some sense, to ordinary consciousness, else no philosophical justification would be needed. However, whatever it is, if anything, that philosophy can provide a justification of, cannot be

\footnotetext{
${ }^{18}$ Fichte, 1794a, p. 71 [FW I, 16].

${ }^{19}$ Fichte, 1794a, p. 67 [FW I, 11].

${ }^{20}$ Fichte, 1794a, pp. 74-6 [FW I, 21-4].
} 
beliefs as held by ordinary consciousness, for these are held without the justification supplied by philosophy. Philosophical justification, if it comes at all, therefore comes too late: at most it bears on reflections, analogues or mere images of the beliefs present in natural consciousness. Jacobi accordingly embraces "the concept of an immediate certainty, which not only needs no proof, but excludes all proofs absolutely, and is simply and solely the representing itself agreeing with the thing being represented." 21 This concept of belief-immanent justification renders philosophical justification otiose, but without it ordinary consciousness can only be regarded in a skeptical light, as lacking all justification.

Fichte would appear to take to heart Jacobi's worry about the corrosive impact of philosophy on natural consciousness. ${ }^{22}$ His response may be put like this: While Jacobi has identified correctly the problem facing traditional attempts at justification of ordinary consciousness, Jacobi has too narrow a view of the range of options, for reasons which are directly related to his failure to appreciate what is distinctive of transcendental philosophy - namely, its insistence on the heterogeneity of transcendental and pre-transcendental forms of explanation. It is possible for philosophical grounds of ordinary beliefs to avoid undermining those beliefs as-held in ordinary consciousness, so long as they are situated at a level that is properly transcendental. And one way of establishing the discreteness of the transcendental level is to construe transcendental grounds Non-Ontologically. The ordinary standpoint conceives explanation ontologically, and to the extent that philosophical grounds are ontological grounds, ones that are missing from the purview of common sense, philosophical justification faces Jacobi's objection. If, however, philosophical grounds are non-ontological, then to cite them is not to bring into the picture anything that is missing - by its own lights - from ordinary consciousness. And so philosophical grounds, when non-ontological, can fulfil their intended justificatory function.

A sharp division of spheres, whereby ontological matters become exclusively the prerogative of ordinary, pre-philosophical consciousness, allows transcendental philosophy to claim that, precisely by not involving itself in ontological commitment, by offering only Non-Ontological grounds, it underwrites the ontological outlook of ordinary consciousness. It also addresses Jacobi's complaint that Kantian philosophy leaves being out of the picture. If ontological claims are categorially inappropriate to transcendental explanation, then transcendental philosophy cannot be criticised as ontologically deficient - on the contrary, it can be claimed to keep being in the picture, precisely by locating it exclusively at the level of ordinary consciousness. In addition, the Non-Ontological turn gives Fichte the basis for answering Jacobi's charge that philosophical systematicity leads inevitably to Spinozism: Fichte can grant this entailment in the specific case of any "dogmatic" philosophy that, like Spinoza's, starts from being and confines itself to ontological explanation, but deny

\footnotetext{
${ }^{21}$ Jacobi, 1785, p. 162 (Eng. trans., p. 230).

${ }^{22}$ E.g. in 1797b, p. 93 [FW I, 508], Fichte endorses Jacobi's view of what it means to prove something (specifically, here: appeal to immediate certainty is involved in the concept of proof). See also Fichte, 1801, p. 42 [FW II, 327] and pp. 45 ff. [FW II, $331 \mathrm{ff}$.], comparing the impact of earlier philosophy on common understanding with that of the WL.
} 
that it is a necessary corollary of philosophical systematicity as such; a transcendental, Non-Ontological philosophical system may be anti-Spinozistic.

The intention of relating the philosophical standpoint to the ordinary standpoint in such a way as to remove philosophical grounds from the categorial orbit of ordinary consciousness, is undoubtedly present in Fichte, and it is very plausible to think that it, in combination with the need to answer Schulze, led Fichte to appreciate what stood to be gained by construing transcendental explanation Non-Ontologically. The WL could accordingly be held to provide grounding explanations of ordinary consciousness without referring to any hidden reality with respect to which ordinary consciousness could be convicted of ignorance, and without carrying metaphysical implications that subvert ordinary belief. Whether, however, this is the whole story, or merely one of several, possibly competing considerations influencing Fichte, is what will be considered next.

\section{Fichte on the status of the Jena Wissenschaftslehre}

In the course of his many attempts to clarify the status of the WL, Fichte shows himself to be engaged intensively with the question of its Ontological/NonOntological status. In this section I will discuss the principal themes bearing on the issue in writings of the Jena period and passages where Fichte addresses the issue directly. In section 5 the evidence of post-Jena writings will be added.

\subsection{Key themes}

Fichte offers a variety of formulations for what it is that the philosopher is doing in giving the account offered in the WL, most often describing it as the construction of a "model [Modell]" of ordinary consciousness that reveals its internal composition. ${ }^{23}$ The general thrust of such statements is to warn his reader off a plain and literal construal of the WL's story: the characterisation of the WL as a model informs us that its dialectic cannot be taken as a description of a directly given object, and that its intelligibility presupposes some special, philosophical understanding of how it is related to its object. Fichte's chief motive in so doing, however, is apparently to bring out the heterogeneity of philosophical thought and the standpoint of life: Fichte wishes to forestall a naive taking-for-real of the WL story, not because he is worried that it may appear metaphysical in the sense of transcending the bounds of sensibility, but because, with an eye to responding to the challenge set by Jacobi, he wants to underline that the philosophical explanations of the WL do not deal in entities that could properly figure as real from the ordinary standpoint, and so that its explanations can neither affect the integrity of ordinary consciousness nor be assessed from its standpoint.

Regarding the distinction of the standpoint of transcendental philosophy from that of life and ordinary understanding, Fichte emphasises three things: their

\footnotetext{
${ }^{23}$ See Fichte, 1799, sects. 6-7, and Fichte, 1801, pp. 61-2 [FW II, 350-2] and pp. 68-9 [FW II, 360-1], drawing the analogy with a watch.
} 
discreteness (they cannot both be occupied simultaneously), the dependence of the transcendental on the ordinary standpoint (the latter is a material necessary condition for the former), and their asymmetric intelligibility (the transcendental standpoint grasps the ordinary, but the ordinary necessarily misrepresents the transcendental). ${ }^{24}$ Once again, what Fichte is consistently concerned to emphasise in these contexts is that philosophical insight "does not create any obstacles for common sense," 25 and though, as said earlier, there is reason to suppose that the thought that this is due to its Non-Ontologicality is present in Fichte's mind, this much is not actually said by him. To that extent, it cannot be concluded from the account given by Fichte of how the transcendental standpoint is distinguished from and relates to the standpoint of life, that it is Non-Ontological.

Some of Fichte's remarks do, however, suggest an outright fictionalist view of the WL. The WL is, he once says, an "instrument" to be thrown aside when its work is done, ${ }^{26}$ and on a number of occasions he calls the WL a "Fiktion." 27 This choice of term is owed to Maimon, and the influence of Maimon's theory of philosophical fictions can be detected in some of the contexts where Fichte employs it. The import of the Maimonian connection as regards the issue of ontological commitment is, however, relatively limited, for a number of reasons. ${ }^{28}$ In general, references to the WL as a Fiktion notwithstanding, Fichte does not characterise the WL in explicitly Non-Ontological terms, as is done when we are instructed explicitly to construe a certain theory in a purely instrumentalist manner: in the main, through the analogies

${ }^{24}$ E.g. Fichte, 1799, sects 5-9; Fichte, 1794b, pp. 200-6 [GA II, 3: 324-33]; Fichte, 1796/99, pp. 105-7 [GA IV, 2: 27; WLnm 24-5].

${ }^{25}$ The quotation continues: "For common sense cannot become conscious of these operations as they have just been postulated (since they condition the possibility of all consciousness and thus lie outside its sphere)," Fichte, 1796-97, p. 25 [FW III, 25].

${ }^{26}$ Fichte, 1799, sects. 6-7.

${ }^{27}$ E.g., Fichte to Schelling, 15 November 1800: "[...] just as transcendental philosophy, through a similar fiction, has consciousness construct itself" [GA III, 4: 361].

${ }^{28}$ Maimon's Non-Ontological "Fiktionen" are, interestingly, connected by him too with the Schulze issue that is so important for Fichte: in Maimon 1794, p. xxxv, "d," Maimon claims that employing fictions to maximise systematic unity is all that philosophy can do given its inability to determine any real ground outside our faculty of knowledge ("einen Realgrund außer dem Erkenntnisvermögen") (quoted in Breazeale, 2002, p. 198). However, Fichte rejects philosophical tenets of Maimon's that are required for the WL to count as a Fiktion in Maimon's sense - see, e.g., Fichte, 1795, pp. 288-9 [FW I, 387-8], where Fichte rejects the "deception" element in Maimon's view - and he does not take up the fictionalist, "als ob" interpretation of the absolute I proposed by Forberg (1797-98, Siebenter Brief, p. 169); indeed he says "the Kantian "as if" is utterly opposed to my system" (letter to Reinhold, 22 April 1799, in Fichte 1988, p. 432 [GA III, 3: 330]). Fichte also does not subscribe to Maimon's formalism. There is a hint in Fichte's Eignen Meditationen über Elementarphilosophie [GA II, 3: 192, Z. 1-5] that Fichte regards Maimon's Fiktion status as one that the absolute I can at least be said to have, rather than, as the only status that it can be said to have. When Fichte, 1801, pp. 98-9 [FW II, 398-9], talks of the WL as a "just as if [gleich als ob]" representation and a "Fiction," it is only to underline that it is (i) not a narrative of true events in time, and (ii) merely isomorphic with that which actually produces real consciousness. This whole question has in any case been discussed very thoroughly in Breazeale, 2002, and Breazeale acknowledges (p. 191) that fictionalism is contradicted by Fichte's description of the WL as a "real philosophy," and that it would obstruct both Fichte's claim for the WL's uniqueness and his refutation of dogmatism; on Breazeale's view fictionalism is not ultimately a contender for the status of the WL but only one element in Fichte's thinking. Part of the appeal of the "Fiktion" label for Fichte is surely to acknowledge how the WL must appear from the standpoint of ordinary consciousness, and perhaps to indicate the dependence which the WL shares with fictions on an act of freedom and their shared semi-autonomy in regard to empirical reality. 
he draws, and by speaking of the philosopher as engaged in "observation" and "experiment," 29 Fichte tells us to understand the WL as a model of something, a "description and representation [Beschreibung und Darstellung]." ${ }^{30}$ A model of what? In one sense, and as Fichte says, the object of the model is simply real empirical consciousness, but since the model through its anatomy thereof leads to the identification of transcendental structures, in another sense it is these, the explanatory transcendental grounds of empirically real consciousness, which are its object. ${ }^{31}$

If attention is now turned to the objects of the WL's modelling in this latter sense, we find that Fichte, in addition to bringing them under his concept of positing, consistently describes them as acts of the human mind. ${ }^{32}$ Fichte emphasises, furthermore, that the identification of these structures is a matter of their discovery the structures have reality and they pre-exist the WL. ${ }^{33}$ Fichte insists on this last point in replying to Schmid's attack on the WL as having fabricated its objects in contrast with Schmid's own putatively Kantian practice of sticking closely to the "facts of consciousness." 34

Yet these statements leave the following to be settled. Even supposing Fichte's ontological commitment to the I of empirical consciousness ("the person"35) to be clear and straightforward, the question concerning the status of the WL is a different question, since this concerns the positings which result from the philosophical modelling of the I; and when Fichte talks, as he does in his reply to Schmid, about the "reality" of the acts, this may mean no more than the WL's assertions are strict necessities of reflection - which would be to say, in NonOntological parlance, just that the perspective which the WL articulates is the true perspective. This may capture all of the force of Fichte's emphasis on discovery rather than invention. This supposition gets some support from other passages where Fichte may be read as saying that the objects of the WL are to be thought of only in relation to philosophical reflection, i.e. where his view may be thought to be that, although philosophical reflection causes acts of positing to appear as objects (even,

\footnotetext{
${ }^{29}$ E.g. Fichte, 1797b, pp. 37-8 [FW I, 454-5]; Fichte, 1796/99, p. 101 [WLnm 21] and p. 120 [WLnm 34-5].

${ }^{30}$ Fichte, 1799, p. 344 [FW V, 342]. See the "model-theoretic understanding" of the WL in Zöller, 1998, pp. 22-3.

${ }^{31}$ To avoid a confusion that threatens at this point: Note that one cannot answer the question by identifying the objects of the WL with the objects constructed in intuition by the philosopher. It is true that there is also a representational relation to be spoken of between (a) the propositions, the Sätzen, of the WL, in the sense of a piece of discourse, and (b) the constructed objects within philosophical consciousness. But to point this out is merely to set the stage for the real question of what is signified by the WL in the full sense of a set of propositions grounded on objects constructed in intuition. It may also be noted that nothing is gained by describing the propositions of the WL as having "merely epistemic" status or significance: the question is how the WL's transcendental conditions function epistemically (whether on an Ontological or a Non-Ontological basis).

${ }^{32}$ E.g.: Fichte, 1796/99, pp. 83-4 [WLnm 8] ("the human mind's original ways of acting," "the inner workings of finite, rational beings"); Fichte, 1794c, p. 126 [FW I, 70] ("acts of the human mind") and p. 132 [FW I, 79] ("corresponds [correspondirt] to an action of the human mind"); Fichte, 1794b, pp. 203-4 [GA II, 3: 328] ("the actions of the human mind itself"); and letter to Reinhold, 2 July 1795, in Fichte 1988, p. 399 [GA III, 2: 344] ("the entire activity of the human mind").

${ }^{33}$ Fichte, 1794-95, p. 120 [FW I, 123-4]. Fichte, 1801, p. 66 [FW II, 357-8] and p. 69 [FW II, 360]: the philosopher "re-invents" a consciousness which is "already there [schon da ist]."

${ }^{34}$ Fichte, 1796, pp. 324-6 [FW II, 444-5], pp. 330-1 [FW II, 451-2].

${ }^{35}$ Fichte, 1796/99, p. 104 [WLnm 23].
} 
as objects having a certain, "ideal" kind of being ${ }^{36}$ ), this is only an appearance, of indirect cognitive value in so far as the philosophical exercise is ultimately instructive. ${ }^{37}$

Further remarks of Fichte's about the concept of activity shows that the designation of the objects of the WL as "acts," like their designation as positings, ${ }^{38}$ does not conclusively determine them as having Ontological status. The strongest single textual consideration favouring a Non-Ontological construal of the WL is the explicit and striking contrast drawn by Fichte on many occasions between being and activity, and his repeated claim that the WL assigns priority to activity over being, and that it is the mistake of other, dogmatic philosophical positions that they reverse this priority. ${ }^{39}$ Fichte describes the concept of being as a negative one, derived from activity by way of its cancellation:

Being is a negative concept [...] In relation to an active subject that is posited as lying outside of being itself, being negates; being cancels productive activity [...] Being is the characteristic feature of the Not-I. Activity is what characterizes the I. Dogmatism begins with being, which it interprets as something primitive and immediate. ${ }^{40}$

It may be wondered if Fichte can speak intelligibly of activity without according it being. The answer lies in the specific way that we are to think activity, namely, from the inside, i.e. by taking up its perspective. In the "Second Introduction" Fichte argues that his employment of the concept of intellectual intuition does not, appearances to the contrary, offend against Kant, when the ambiguity in that notion is recognised. Defined as cognition of things in themselves, claims for intellectual intuition are unKantian, but the WL, Fichte says, decouples the notion of intellectual intuition from that of thing in itself: intellectual intuition as he conceives it "is not directed toward any sort of being whatsoever; instead, it is directed at an acting." 41 The being/acting opposition we have encountered earlier, but here Fichte adds an explanation of what it is for intellectual intuition to be "directed at an acting:" it is, he says, quite simply the mode in which we are "conscious of the categorical imperative." Now this mode of consciousness is very plausibly, on a Kantian analysis, ontologically uncommitted. ${ }^{42}$ So if the WL is the explication of intellectual intuition, and if this intuition has no ontological character, then the Non-

\footnotetext{
${ }^{36}$ E.g. Fichte, 1797b, p. 80 [FW I, 494], where Fichte does attribute "ideal being," or "sheerly ideal being," to the WL's acts.

${ }^{37}$ E.g. Fichte, 1797b, pp. 78 [FW I, 492-3] and p. 84 [FW I, 498]. Another caveat regarding the realism appropriate to the WL's objects also seems to be provided by their description as (schematic) "images," Fichte, 1794b, p. 203 [GA II, 3: 328].

${ }^{38}$ See Zöller's gloss on "setzen," 2001, pp. 140-2.

39 Fichte also defines his differences from Schelling in these terms: see FW XI, 368-70.

${ }^{40}$ Fichte, 1796/99, p. 131 [GA IV, 2: 39; WLnm 41-2]; see also p. 67.

${ }^{41}$ Fichte, 1797b, p. 56 [FW I, 472].

${ }^{42}$ That is, with regard merely to its obligating character, holding aside its arguable metaphysical presuppositions. See Fichte, 1798a, p. 56 [FW IV, 54]: "the manner in which something is thought therein [in the categorical imperative] has been called an "ought," as opposed to a "being" [man hat die Weise, wie in ihm etwas gedacht wird, zum Gegensatze des Seyns als ein Sollen bezeichnet]."
} 
Ontological status of the WL can be inferred directly. The WL could then be understood as the discursive presentation of perspective in the sense described earlier, where the perspective in question is that of practical necessity, of having-to, obligedness-to, or its-being-demanded-of-one-that. ${ }^{43}$ This coheres with another key theme in Fichte, his description of the principles of the WL as "postulates," his claim that "the scope of Kant's practical postulate is too narrow" and that "consciousness in its entirety is included within" it. ${ }^{44}$

\subsection{Key passages}

Having identified the principal themes in connection with which the issue of ontological commitment arises, I want now to look at passages where Fichte broaches it directly.

1. Grundlage, §4. In what must be Fichte's earliest discussion of the issue, in the theoretical part of the Grundlage, Fichte suggests a complex view that brings together several of the points discussed above. ${ }^{45}$ Fichte describes the object of the WL (specifically, here, the positing expressed in its second principle) (i) as a "fact," "in a higher sense of the word" (than, presumably, Reinhold's), yet (ii) as one which is "artificially brought forth according to the rules of reflection," "artificially engendered through the spontaneity of philosophizing." Fichte then adds the qualification that (iii) this artifice pertains only to the "consciousness" of the fact, not to the fact itself, and in any case insists (iv) that what is in question (as corresponding to the principle) is "a primordial fact occurring in the human mind." At the same time Fichte says, twice, (v) that philosophical knowledge is only of "something" in our mind that corresponds to the principle, suggesting that this corresponding "something" does not exist as originally present in our mind in the form which is displayed by the objects engendered by philosophical reflection. ${ }^{46}$ Fichte is here, therefore, apparently seeking to affirm a realistic, representational understanding of the WL at some level, while slackening its relation to the ontological domain in a way that allows it to be thought that, while the positings of the WL do indeed indicate some ontological item(s), they themselves lack direct reference and should not be ascribed Ontological status.

2. Foundations of Natural Right, First Main Division. Towards the beginning of the Foundations of Natural Right Fichte poses squarely the question of the Ontological/Non-Ontological status of the WL:

\footnotetext{
${ }^{43}$ It is a further question whether this is generic practical or specifically moral necessity. In this place at least Fichte seems to envisage consciousness of the moral law only as a means to illuminate practical self-consciousness in general. Its privilegedly pre-mundane, hence transcendental character is emphasised in Fichte, 1794a, p. 75 [FW I, 22].

${ }^{44}$ Fichte, 1796/99, p. 298 [GA IV, 2: 139; WLnm 146]; see also pp. 109-10 [GA IV, 2: 28-9; WLnm 28].

${ }^{45}$ Fichte, 1794-95, pp. 196-7 [FW I, 219-20].

${ }^{46}$ Fichte often draws attention to the artifice involved in the WL's representation of what is essentially unitary as a composite of separate, as if temporally distinct, actions; see, e.g., Fichte, 1796/99, pp. 1023 [WLnm 22-3].
} 
One might ask: if reality belongs only to that which is necessarily posited by the I, then what reality [Realität] is supposed to belong to those actions that lie outside the sphere of all consciousness and are not posited within consciousness? ${ }^{47}$

His immediate answer - "Obviously, no reality except in so far as it is posited, and thus merely a reality for philosophical understanding" - refers us on to the question of what it is for something to have posited-reality, reality-for-philosophicalunderstanding. Philosophical understanding is defined, Fichte says, in terms that stick close to Maimon, by its aim "to unite the operations of the human mind systematically in an ultimate ground." 48 This aim makes it necessary "to assume" that such and such are "actions [Handlungen] of the human mind." The question then becomes what we must think about the Ontological/Non-Ontological status of thatwhich-we-must-assume in discharging the cognitive task at hand. And here Fichte draws an analogy. Primitive peoples, he supposes, lack an interest in the unity of experience and consequently allow "individual perceptions to lie scattered about within their consciousness:" for them, the universal connection of things in causal reciprocity, affirmed in Kant's Analogies, "does not exist at all." It does exist, and has reality, however, for we who seek unity of experience. And this, Fichte claims, provides the right analogy for thinking about the Ontological/Non-Ontological status of the WL: its positings have "the same reality" for philosophical consciousness, i.e. in relation to the interest in an unconditioned ground of cognition, as the causal order has in relation to ordinary consciousness, i.e. in relation to the interest in systematic unity of experience.

The trouble with this analogy is that it can be taken to count equally either for or against an Ontological interpretation of the WL, depending on how it is drawn. On the one hand, since the causal order is transcendentally ideal, the analogy suggests that the WL be viewed as a construction merely internal to philosophical consciousness; on the other hand, since ordinary consciousness does at its own level take the causal order to be fully ontologically real, and there is no supertranscendental level to "correct" the philosophical standpoint, the analogy suggests that the WL be taken Ontologically. What would decide between these two interpretations would be a categorical claim about the status of the interest which defines philosophy and relative to which philosophical objects have reality - a statement to the effect either that the unconditioned unity of cognition is merely a subjective need of our reason, or that it expresses ontological necessity. But Fichte does not make either claim, with the result that the Ontological/Non-Ontological status question is again left undecided. What Fichte instead considers it important to underline is once again the discreteness of levels, complaining that philosophically inferior minds fail to "pay attention to the reality that is being highlighted here" and insists on "reducing it to the kind of reality they are familiar with."

\footnotetext{
${ }^{47}$ Fichte, 1796-97, p. 25 [FW III, 25].

${ }^{48}$ Ibid.
} 
3. Replies to Forberg in the "Second Introduction" and "Postscript."

Forberg alleged a dilemma regarding the ontological status of the absolute I of the WL's first principle. Forberg argued that it cannot be a "Something," since if it were it could not be an absolute principle, and yet cannot be a "Nothing," since a nothing cannot be a principle. So it must be, as he puts it, "a third thing between them" 49 - an incoherent status, Forberg argues, that Fichte tries to conceal by attributing "ideal being" to the I. This, Forberg continues, is no more effective a way of showing the possibility of the absolute I than the possibility of a square circle can be established by according it "ideal being." 50

Fichte replies to Forberg in the "Second Introduction," and in an editorial "Postscript" to Forberg's essay, where he writes:

The entire presupposition that underlies this question, that is, the assumption that everything that we can talk about must either be or not be, is completely inadmissible and dogmatic. Our philosophy is acquainted with something that is even higher than any being [kenne etwas, das da höher liege, als alles Seyn]. In short, we replied that our A neither is nor is not; in no possible sense is "being" a predicate of this A. ${ }^{51}$

This may seem to leave no room for doubt that the positings of the WL are NonOntological. In a moment more textual evidence for resisting this conclusion will be adduced, but for now the point to make is just that, for all of the above, it remains thinkable that in Fichte's denials that the WL's transcendental can be brought under the concept of being, he is employing the concept of being in a restricted or narrow sense, ${ }^{52}$ in a form determined for application to objects-for-a-subject - in the same way, or in a way analogous to that in which, for Kant the concept of existence has a schematised form, in which it can be applied only to empirical objects, and an unschematised form, employed when Kant speaks of the existence of things in themselves. Indeed this is how Schelling in the System of Transcendental Idealism replies to Forberg, namely by distinguishing different senses of being. ${ }^{53}$

\footnotetext{
${ }^{49}$ Forberg, 1797-98: "The difficulty was this: if an absolute principle of all things is to be found, then it must in the first place not be Nothing, for it would then be no sort of principle; and in the second place it must also not be Something, for it would then not be an absolute principle. No third thing between the Something and the Nothing offers itself as thinkable. Thus it appears an altogether incoherent undertaking to search for an absolute principle - something it is impossible to find" (Zweiter Brief, p. 156); "Consequently the absolute I would have to be neither Something nor Nothing: it would have to stand between a Something and a Nothing, thus in the middle between two contradictorily opposed terms, and this would be according to all the rules of thought the highest of inconsistencies" (Zehnter Brief, p. 173).

${ }^{50}$ Forberg, 1797-98, Zehnter Brief, p. 174.

${ }^{51}$ Fichte, 1798b, p. 137 [GA I, 4: 466]. See also Fichte 1798a, pp. 40-1 [FW IV, 36-7].

${ }^{52}$ See Lachs, 1987-88, pp. 171-2.

${ }^{53}$ Schelling, 1800, p. 32 [SW II, 375-6]: the self, "since it is the principle of all reality," cannot have being of the derived sort that attaches to things: rather it "is being-itself [das Sein selbst]," selfsupporting being, which we think through a concept "higher than that of any thing," namely that of "doing, or activity." Schelling later criticises Fichte's attempt to avoid speaking of activity in terms of being: Schelling, 1802, p. 199 [SW III, 199].
} 
Other comments of Fichte's in the context of his reply to Forberg do suggest that he is talking about, in Kant's terms, schematised versions of the categories, and it is also important that Forberg indicates that he regards "being" as univocal and as adequately grasped through attention to any ordinary conditioned existent, such that it would be reasonable for Fichte to assume in this context of argument that only a restricted sense of being - one fashioned in accordance with the outlook of ordinary, non-transcendental consciousness - need be regarded as in play. To this must be added that Fichte does not explain his "neither-is-nor-is-not" position by retreating to any claim to the effect that the WL is "merely a model," nor by adding a Kantian rider: he does not say merely that we are "forced to assume," or "need to think," something higher than being for the transcendental purpose of making sense of our epistemic relations. Rather his claim is to be actually acquainted with "something that is even higher than any being."

This would leave it open that the Fichtean transcendental, Fichtean activity, can be brought under an unschematised, indeterminate concept of being - even if, in the context of explaining to Forberg his errors, it can serve no purpose for Fichte to spell this out.

The further evidence that Fichte is by no means of one mind as regards the refusal of some sort of attenuated Ontological status to the transcendental or activity includes a footnote in the Grundlage which attributes "absolute being [absolutes Seyn]" to the transcendental level of the I's positings, ${ }^{54}$ and the many places where Fichte does not say that being is categorially inapplicable to the I but rather that its being is its self-positing or activity:

The sole type of being of the I [Seyn des Ich] with which we are here concerned is the being which it possesses within the self-intuition we have now described; or, more rigorously expressed, the being of the I with which we are concerned is the being of this intuition itself. ${ }^{55}$

This statement is of particular importance, first because Fichte claims to be speaking here from a "higher speculative standpoint [höheren Standpunct der Speculation]"56 than that from which he had earlier in the text denied that being belongs to the $\mathrm{I} ;{ }^{57}$ and second because, in what immediately follows, Fichte explicates his claim through a denial that the I has being over and above its self-intuition, thus seeming to confirm that this self-intuition is indeed a case of being.

It is furthermore possible to explain more fully why the idea that activity does after all have Ontological status should not be taken to be ruled out by Fichte's opposition of being and activity. In the "Second Introduction" Fichte writes: "what is comprehended within this intuition becomes comprehended through its opposition to mere being. 'Acting is not being, and being is not acting:' this is the only definition of

\footnotetext{
${ }^{54}$ Fichte, 1794-95, p. 245n [FW I, 278 Anm.].

${ }^{55}$ Fichte, 1797c, p. 114 [FW I, 529]. This prompts us to reconsider Fichte's ambiguous claim that the faculty of representation "exists only for" itself as, after all, a genuine Ontological claim.

${ }^{56}$ Fichte, 1797c, p. 110 [FW I, 525].

${ }^{57}$ Fichte, 1797c, p. 109 [FW I, 524].
} 
acting one can obtain from its mere concept." 58 That is, Fichte may be understood to be saying, at the level of concepts, and only in so far as we proceed through them, do we arrive at an opposition of being and activity. ${ }^{59}$ The reason for this lies, plausibly, in Fichte's view of the impossibility of representing conceptually the kind of being possessed by activity: concept-application, or judging, is a case of determining a subject, and so necessarily construes the subject non-actively; whereas in acting what we have is, as it were, a subject turning itself over into a predicate. ${ }^{60}$ This suggests that acting is opposed to being, not as the Non-Ontological to the Ontological, but in a way closer to that in which, in traditional metaphysics, becoming is opposed to being, ${ }^{61}$ or, in romantic language that Fichte often employs, living being is opposed to "dead permanency." 62

Second, there is the apparently procedural or methodological character of the priority of activity over being. This comes out more clearly in $\S 2$ of the "Second Introduction." What Fichte here takes to be the very first philosophical question, namely "What is the origin of the system of representations accompanied by a feeling of necessity?," is, he says, equivalent to the question, "how do we come to assume the existence of any being?," or "how is a being for us possible?;" and to answer this question correctly requires, he says, in proto-Husserlian terms, that one "abstracts from all being" and ceases to employ the concept of being. ${ }^{63}$ The point is therefore that, in addition to its arguably resting on a restricted application of the concept, Fichte's setting-aside of being is only preparatory: here Fichte is only telling us what is needed to come to form a concept of the transcendental standpoint, not yet describing what we apprehend from it, viz. activity. ${ }^{64}$

4. Second Introduction to the Wissenschaftslehre novo methodo. In a subsection titled "Relation of this system to experience," 65 Fichte again poses the question: "philosophy encompasses a system of those actions by means of which objects come into being for us. But do these actions described by idealism actually occur? Do they possess reality, or are they merely invented [erdichtet] by

\footnotetext{
${ }^{58}$ Fichte, 1797b, p. 45 [FW I, 461].

${ }^{59}$ W. Martin, 1997, p. 52, draws attention to this point. Supporting this interpretation is Fichte's letter to Schelling, 31 May 1801: "everything toward which mere thought is directed and, in consequence of this, to which the real ground [Realgrund] is applied, is being [Seyn];" later in the letter Fichte describes being as "seeing that does not penetrate itself," but the being in question is only the determined being of "given actuality [gegebnen Wirklichkeit]" [GA III, 5: 46]. This supports the contention that the being/activity opposition turns on a restricted sense of being, and that Fichte is not in the habit of marking explicitly this restriction even when he has it in mind.

${ }^{60}$ See Fichte, 1799, p. 372 [FW V, 367]: "My feelings, desires, thinking, willing, etc., I know of immediately by accomplishing those acts. They come into my consciousness by no act of mediation, but only by my positing them, by my being in them [daß ich in ihnen bin]." Also relevant here is Fichte's agent-causationism: see, e.g., 1798a, Introduction, p. 9 [FW IV, 3].

${ }^{61}$ Which is how Schelling puts it, 1797-98, p. 79 [SW I, 291].

${ }^{62}$ Fichte, 1799, p. 371 [FW V, 366]. In this connection see Lachs 1987-88, pp. 171-2, and Bourgeois, 1995, pp. 99-101.

${ }^{63} 1797$ b, p. 39 [FW I, 456].

${ }^{64}$ Fichte's tendency to vacillation between seeming to say that the absolute I is altogether preontological, and merely that it cannot be ascribed determinate objectual being - the latter prevailing ultimately - is magnified in Schad's presentation of the WL: see Schad, 1800, pp. 117-18.

${ }^{65}$ Fichte, 1796/99, pp. 102-5 [GA IV, 2: 25-7; WLnm 22-4].
} 
philosophy?"66 Fichte's answer here, while repeating some points already seen, introduces a new claim concerning what "reality for philosophical understanding" amounts to. If actual existence or reality is taken empirically, Fichte says, then of course the WL's actions do not really exist, but this is not the only, or the most basic sense of existence: on the contrary, "in this system there is no other sort of reality [Realität] at all except for reality of the sort indicated (i.e., necessity of thinking);", the acts of the WL "possess the reality of necessary thinking, and it is for necessary thinking that reality exists." 67

It is not at all obvious how Fichte's statement can be taken to answer the question. Fichte is of course reminding us that the WL affirms the transcendental ideality of objects in general and he is suggesting, presumably, that because the grounds of necessary thinking are themselves thought within the WL, transcendental idealism supplies the answer to the metaphilosophical question at hand. But what exactly does this answer comprise? In particular, is "being the content of necessary thinking" and "having real existence" one or two states of affairs? It is hard to see how it can be the latter - Fichte cannot be affirming a principle of inference from necessary thought to existence an sich, since he has conceded to Schulze that point entirely. Can it be the former? If so, clarification is needed. What does "really exists" add to "must be thought"? Presumably it adds something, else Fichte would have said that the WL replaces talk of Realität with talk of necessary thinking, reducing the former to the latter, and that is not what he does: instead he ascribes reality to necessary thinking, suggesting a symmetric relation of equivalence rather than an asymmetric relation of reduction. This however raises a question: What conception can we have of a unitary state of affairs that incorporates an equivalence of "real existence" and "necessary thinking"? Under what condition can we credit ourselves with such a notion? In the final section I will make a suggestion as to Fichte's meaning here.

\section{Non-Ontological interpretation of the Wissenschaftslehre}

The purpose of the foregoing textual discussion has been to show that the issue of the Ontological/Non-Ontological status of the WL is a central preoccupation of Fichte's, and to make clear the existence of tensions on this score in Fichte's thinking: despite the initial motivation deriving from problems of Kant reception, Fichte's shift to a Non-Ontological conception of philosophical explanation is not clean and complete. Fichte's model analogy and insistence on the reality of the objects of the WL, though not excluding a Non-Ontological interpretation, invite an Ontological reading; while Fichte's remarks on the derivative character of the concept of being, which may initially appear clear repudiations of ontological commitment, nevertheless leave it open that the activity to which Fichte counterposes being has Ontological status in a sense different from that which he denies, and in this section further reason will

\footnotetext{
${ }^{66}$ Fichte, 1796/99, p. 102 [WLnm 22]. Fichte on this occasion has J. S. Beck in mind as his critical interlocutor.

${ }^{67}$ Fichte, 1796/99, pp. 103-4 [GA IV, 2: 27; WLnm 23].
} 
emerge for thinking that Fichte's apparently Non-Ontological characterisations of "activity" do not settle the issue. Furthermore, Fichte's attempts to address the Ontological/Non-Ontological question directly, we saw in 4.2, leave much undecided; not even the pressure supplied by Forberg produces an unequivocal resolution. ${ }^{68}$

Given the indeterminacy of Fichte's texts, the WL should next be considered in a more systematic spirit: Are there any general considerations pertaining to Fichte's philosophical project that decide the Ontological/Non-Ontological issue? In this section I will first consider an interpretation of the WL that has considerable plausibility and that would, if correct, establish conclusively its Non-Ontological status. I will then offer criticism of the (widely held) view that a Non-Ontological reading is required in order to prevent the WL from being assimilated to traditional metaphysics.

1. The regulative interpretation of the Wissenschaftslehre. According to one prominent interpretation, the primacy of the practical provides the key to the WL, and should be taken to mean not just that the WL has practical grounds, but that it has a global regulative status. The WL as a whole is interpreted as an extension of Kant's doctrine of the moral postulates, ${ }^{69}$ and as such, may be regarded as offering an explanation of the world in Non-Ontological, imperatival terms: it presents the world under the transcendental-perspectival aspect of our having-to. ${ }^{70}$

As the textual material reviewed above in section 4.1 showed, this idea has support. The central issue that it raises can be brought out by drawing the contrast with Kant. In Kant, regulative employment of reason is understood against a constitutive background. Regulativity is given definition and held in check by the prior account of constitutivity: we learn that we must only employ reason's transcendental ideas regulatively, after we have learnt that contradiction results from, and that illusion underlies, their constitutive employment; just as practical reason's employment of those ideas comes in the wake of theoretical reason's failure to employ them constitutively. If, however, the constitutive background is eliminated, then the question arises, whether what is now called regulative does not in fact carry part of the meaning of Kant's constitutive, or at least, whether "regulative" can continue to bear unchanged the same non-ontological meaning as it bears in Kant. When regulativity does not occur in opposition to constitutivity, the imperatival mood of putatively regulative principles ceases, one may think, to be a reliable index of

\footnotetext{
${ }^{68}$ The ambiguities of the WL are reflected, in magnified form, in Novalis' Fichte studies. See, e.g., Novalis, 1795-96, pp. 105-6 (Eng. trans., p. 5): [2.], "Concerning Consciousness:" consciousness is "a being outside of being that is nevertheless within being [ein Seyn außer dem Seyn im Seyn]," and what is "outside of being" is "no proper being [kein rechtes Seyn]."

${ }^{69}$ See Beiser, 2002, pp. 233-4, 238. See also Mandt, 1984.

${ }^{70}$ Another Non-Ontological interpretation of the WL, which there is no space to consider here but which should be noted, is Philonenko's interpretation of the WL as engaged in transcendental dialectic, in Kant's sense (Philonenko 1966, 1973, 1987-88). Philonenko considers that Fichte means to reverse the order of the first Critique, and that the WL, from its first principle up to the "Deduction of representation," is a logic of illusion, designed to puncture the ontological pretensions of the I: "The absolute I is not an absolute being, as Schelling supposes, and similarly Hegel, but an idea, which one must prevent oneself from hypostatising" (Philonenko, 1973, p. 917). Philonenko's view is endorsed in Ferry, 1990, pp. 82-3. Exegetical issues aside, on my view this interpretation faces difficulty in accounting for the WL's claim to supply a logic of truth, in so far as this is held to merely follow from the negative work of transcendental dialectic.
} 
their philosophical significance. So when Fichte describes the Wissenschaftlehre's principles as postulates, the question is whether his proposed extension of the postulates' scope can leave unaffected the understanding of what it is to "postulate." One may think that, although Fichte is entitled to use the concept of postulation to draw attention to a continuity with Kant, really its meaning for Fichte has to be understood via the WL, not the other way round. ${ }^{71}$

It may be responded that, whatever the value of this point, it does not refute the contention that Fichte himself regarded the WL in a regulative light. This is true, but there are in any case reasons for doubting that Fichte's view of practical consciousness is exhaustively Non-Ontological. What first of all deserves emphasis is that the Non-Ontological view does not follow directly from Fichte's commitment to the primacy of the practical: just as (we saw) Fichte's exclusion of being from the WL can be understood methodologically, as leaving space for ontological recharacterisation at a higher speculative level, so can his appeal to non-ontological pure practical consciousness, and in later texts (from early 1799) there are clear signs that it is Fichte's view that practical consciousness has an ontological dimension. By 1800, in The Vocation of Man, an explicit Ontological interpretation of the practical emerges. It is worth spelling this out, in order to show that no obvious discontinuity with earlier versions of the WL is involved.

In Section IV of Book III of the Vocation, having completed a partial exposition of what realising humanity's vocation requires, in terms of individual conformity to the moral law and its collective realisation in historical progress, Fichte presents a carefully plotted series of transpositions of consciousness of moral vocation into different sets of philosophical terms. ${ }^{72}$ (1) First, Fichte re-expresses our situation in Kantian two-worlds language, of a sensible and a supersensible world each governed by a different law, which we yet unify. This can be taken in "constructivist" terms, the supersensible world having being only in so far as it is constituted by the actions of finite moral subjects. ${ }^{73}$ (2) But Fichte then makes a second transposition, reconceiving the moral law as a "will," the single unitary will of the supersensible world, ${ }^{74}$ to which an ontological characterisation is attached: in so far as my own will is moral, "I am connected with the One that is there, and take part in its being [So stehe ich mit dem Einen, das da ist, in Verbindung, und nehme Theil an seinem Seyn]." 75 The Ontological status of the will or the One goes beyond what constructivism provides for, but its existence is still correlated with the individual moral will. (3) In a third movement - after an excursus in which Fichte argues that

\footnotetext{
${ }^{71}$ See for example Fichte, 1794-95, p. 196 [FW I, 219], where the second principle of the WL is described both as a postulate and said to correspond to a fact of the human mind. Schelling, provoked by what he regards as widespread misuse of Kant's concept, demonstrates a considerably fuller awareness of the complex alteration that the concept of postulate (and an "intensified practical reason") undergoes in its post-Kantian employment: see Schelling, 1795, pp. 158-9, 168, 190-2, 195 [SW I, 210-12, 224-5, 257-9, 264], and 1797-98, esp. Appendix: On Postulates in Philosophy, pp. 1328 [SW I, 368-76]. Postulation, on Schelling's early account, is related to the immediate thinking of absolute being: see Schelling 1975, pp. 190-1 [SW I, 256-7].

${ }^{72}$ Fichte, 1800, pp. 103-12 [FW II, 294-305].

${ }^{73}$ Fichte, 1800, pp. 103-5 [FW II, 294-7].

${ }^{74}$ Fichte, 1800, pp. 106-7 [FW II, 297-9].

${ }^{75}$ Fichte, 1800, p. 107 [FW II, 299].
} 
this One Will must be adduced as the transcendental ground of there being a single sensible reality common to all finite subjects; implying that it must extend beyond individual subjectivity ${ }^{76}$ - the ontological characterisation is taken one step further: Fichte talks of "the One Eternal Infinite Will" or "infinite reason" as that which is "the creator of the world," which "intervenes in our minds through the call of duty" and "maintains this world and thereby our finite existence." 77

It is worth adding that this Ontological reading of the Vocation is also given by Hegel in the Phenomenology: the so-called "moral world-view" comes to completion, Hegel thinks, with an attempt (albeit abortive) to determine "absolute Being." "78 To be sure, Hegel describes this being as postulated: but the point, which Hegel correctly sees in Fichte and underscores, is that what is postulated is postulated precisely as having being, not postulated as having merely postulated status.

The quasi-Platonic outlook of the Vocation is developed extensively in the post-Jena WL. In the 1804 WL transcendental enquiry first burrows down to a point where pure being, which has existence "of itself, in itself, and through itself," is encountered, and then follows being's self-construction through the Sollen, "illuminated for us as an absolute that holds and sustains itself out of itself, of itself, and through itself as such, on the condition that it exists [unter Bedingung, daß es sei]."79 The 1804 WL reproduces, while seeking to describe more amply, the same ontological structure as Fichte describes at the end of the Vocation.

Now it is of course true that all this belongs to a later phase in Fichte's thinking, but the question is how much change or continuity should be seen in Fichte's development. We should be reluctant to attribute to Fichte the volte face implied if we suppose him to have switched from one metaphilosophical view to its opposite. ${ }^{80}$ It is, I suggest, more plausible to regard Fichte as at least not fully committed in the Jena WL to the Non-Ontological conception - this is in any case, I

\footnotetext{
${ }^{76}$ Fichte, 1800, pp. 107-10 [FW II, 299-302].

${ }^{77}$ Fichte, 1800, pp. 110-11 [FW II, 302-4]. For an anti-realist reading of Vocation - as just practical postulation - see Breazeale, 2002, p. 194. Zöller, 1998, pp. 125-6, considers that the supra-individual will is "nothing else than" the moral law, and that its deification may be put down to the work's popular presentation, but acknowledges that there is an "indication" of a "contemplative" stance towards the noumenal world (later developed by Fichte), which (I assume) Zöller regards as ontologically committed. Heimsoeth, 1923, ch. 5, gives a straightforwardly Ontological interpretation of Fichte's Religionslehre, emphasising its immanentism and its departure from Kant's postulate theory (pp. 176-7); Heimsoeth considers this motive to have been present, but unclarified, in the Jena WL (p. 194). See also Bourgeois, 1995, p. 103.

${ }^{78}$ Hegel, 1807, §599-631 [HW III, 441-63], “The moral view of the world,” esp. §§611-2, §616, §626, $\S \S 630-1$ [HW III, 449-51, 452, 459-60, 461-3]. Hegel analyses the ontological commitment of moral consciousness in terms of consciousness' attribution to its object of (a) "an intrinsic being of its own [Anundfürsichseiende]" (§616) [HW III, 452], "an existence and a reality [Dasein und Wirklichkeit]," "not as an unrealised "thought-thing"” (\$630) [HW III, 461], which is (b) located "in another being than the actual consciousness" (§626) [HW III, 459]. We know (e.g., from Hegel, 1802, C., "Fichtean Philosophy") that Hegel regards the Vocation as a central presentation of Fichte's position.

${ }^{79}$ Fichte, 1804, pp. 131-2 [FW X, 227].

${ }^{80}$ Vater, 1994, suggests that in 1801-02 Fichte under pressure from Schelling inconsistently compromises the WL by admitting transcendent "absolute being," himself becoming a "Spinozist" ( $p$. 192). Yet if what I argue later is correct, this at most reflects a flaw in the 1801-02 presentation of the WL's ontological dimension.
} 
have argued, what the texts themselves suggest - and as having arrived at a definite view only in his post-Jena reflections. ${ }^{81}$

Much speaks in favour of this assessment. For instance, it is surely of significance that the 1804 view can be regarded as an attempt to explain what was meant a decade earlier in the obscure footnote in the Grundlage referred to earlier. ${ }^{82}$ And in view of the point made earlier regarding the likely changed meaning of "postulate" in Fichte, it would not be surprising if Fichte's commitment to the primacy of the practical failed to shake the WL free of ontological commitment. As noted, already in Kant there is the beginning of uncertainty as to what becomes of the practical/theoretical distinction through the moral theology, and there is additional reason to think that in Fichte the meaning of the distinction must alter. For, when Kant allows practical reason to declare that the ideas of God and the soul have objective reality, these ideas are still, so to speak, on loan from theoretical reason, and this gives force to the "merely" in Kant's assertion that their objective reality is merely practical. But when Fichte makes practical reason fundamental and allencompassing, this is no longer the situation, and if the operations of Fichtean practical reason reveal a capacity to determine objects with genuine ontological status, in a way this is just what might have been expected.

2. The Wissenschaftslehre and metaphysics. Nothing yet argued affects the earlier point that a strong motive for reading Fichte Non-Ontologically appears to lie in the concern to do justice to Fichte's insistence on the distinctiveness of the transcendental standpoint and to duly distance Fichte from any traditional "dogmatic metaphysics of the subject:" 83 a distance which any Ontological interpretation of the $\mathrm{WL}$ - a style of interpretation characteristic, it may be thought, of older generations of Fichte commentators ${ }^{84}$ - may appear to reduce or eliminate. It needs now to be asked how much weight should be accorded to this motive.

(i) If the concern is to do justice to Fichte's own perception of the distance, this can be accommodated by construing the difference between Fichte's transcendental philosophy and traditional metaphysics, not in terms of the NonOntological/Ontological distinction, but in methodological terms. On this view, Fichte's characterisation of the metaphysics that, he affirms, Kant has forever disposed of, is methodological, ${ }^{85}$ and sets no limits on the content of transcendental philosophical claims: so long as the latter are arrived at in the right way, viz. by extrapolation from the transcendental conditions of empirical knowledge and moral will, and do not attempt to "produce an object by mere thought" or mere "argumentation," their content may include ontological assertion regarding supersensible objects. Transcendental philosophy's inventory of existents may thus overlap with that of traditional, pre-Kantian metaphysics, the difference between them, on this account, being that the latter has passed through the purgative methodological fires of Kant's first Critique.

\footnotetext{
${ }^{81}$ See Hartmann, 1923, pp. 80 ff., on the continuity in Fichte's development.

${ }^{82}$ Fichte, 1794-95, p. 245n [FW I, 278n].

${ }^{83}$ Zöller, 1998, p. 39.

${ }^{84}$ E.g., Martial Gueroult, or Heinz Heimsoeth.

${ }^{85}$ See Fichte, 1799, pp. 341-2 [FW V, 339-40], and Fichte, 1801, pp. 45-6 [FW II, 331-2].
} 
(ii) In so far as the aim is not so much to avoid landing Fichte with a generally pro-metaphysical position, but to avoid saddling him with the specific, especially objectionable metaphysical claim that there exists an absolute self (which gives birth to the world, etc., as per the standard caricature), it may be objected that this is to confuse two properly distinct issues. Fichte's claim that the self posits itself as absolute sets of course a major interpretative challenge, but (quite apart from the question of whether it can receive a plausible Non-Ontological exegesis ${ }^{86}$ ) this is not well met by de-Ontologising the WL as a whole, a move that in fact concedes to the standard caricature precisely what should, arguably, be contested in it: namely its assumption that Fichte's claim that the self "posits itself as absolute" can only have the kind of meaning that such a statement would have in pre-Kantian philosophical discourse. The problem with the standard caricature, it may be suggested, is not that its reading of Fichte is Ontological, but that it strips Fichte's ontological claims of their distinctive post-Kantian sense and grounding.

(iii) To the extent that the worry is epistemological - the thought being that an ontological story is somehow less secure than a non-ontological - it appears misguided, for if the WL, under a Non-Ontological interpretation, has the epistemological warrant that it requires, then it must enjoy the same warrant under an Ontological interpretation; changing the status cannot of itself incur an epistemological penalty. As it might be put, if we know that the WL is the right story to tell, then why hold back from an Ontological interpretation?

(iv) To the extent that the worry about narrowing the gap between Fichte and traditional metaphysics has its source in a contemporary reconstructive motive of ours - namely to show that Fichte is on the same side of the fence as a sober naturalistic outlook in his opposition to metaphysics ${ }^{87}$ - it again appears wrongheaded, in so far as the WL on a Non-Ontological interpretation (even one which holds the posited-being of nature to be compatible with realism) continues to contradict philosophical naturalism in a way that, although different from, goes every bit as deep as any ontological assertion of supernatural objects, by virtue of its committing Fichte to a conception of philosophical explanation that is unintelligible from the naturalist standpoint.

\section{Internalising the Ontological/Non-Ontological distinction: Fichte, Schelling, Hegel}

I hope to have indicated a limitation of what I take to be the most plausible NonOntological interpretation of Fichte, and to have cast doubt on the supposition that a

\footnotetext{
${ }^{86}$ On the issue of whether Fichte can and should be "freed" from ontological commitment to an absolute self, I am in agreement with Lachs 1987-88 in his criticism of Mandt, 1984, though Lachs' own Ontological reading of the claim is not in my view optimal. Beiser, 2002, pp. 284-8, offers a more convincing Non-Ontological reading of the claim than Mandt, but continues to face a problem, in my view, concerning what it means to say that the self is, as Beiser puts it, "absolute only in a formal sense."

${ }^{87}$ Even Zöller, whose interpretation of the WL is not Non-Ontological, endorses the impetus to avoid a "metaphysical reading" of Fichte, and talks of steering a "middle course" between naturalism and "supranaturalist metaphysics" (1998, pp. 38-9).
} 
Non-Ontological reading is required in order to avoid a damagingly "metaphysical" interpretation of Fichte. I now suggest the following as an overall assessment of the WL's status.

Fichte's position does incorporate a Non-Ontological turn, in so far as he, inheriting Kant's ambiguity regarding the status of the transcendental, and aware of how a non-ontological construal would furnish a solution to the problems posed by Schulze and Jacobi, sees what is to be gained by identifying philosophical explanation with the articulation of perspective, and accordingly employs the nonontological perspective of practical consciousness as transcendental ground. This could have resulted in a consistently Non-Ontological outlook and, had the WL been developed no further, would have done so. Fichte's position is, however, not ultimately Non-Ontological: while Fichte considered a Non-Ontological conception of the transcendental sufficient to discharge at part of the task of philosophy, he did not regard transcendental explanation as necessarily Non-Ontological, and ontological characterisation of the transcendental is present, albeit in an imperfectly clear form, in the Jena writings, while in the post-Jena period - provoked by critics, above all Schelling and Jacobi, to rectify the WL's appearance of ontological deficiency but in his own eyes simply following out the logic of his position - Fichte situates the transcendental perspective in a firmly ontological setting. This strategy gives Fichte a coherent and defensible position: having initially freed transcendental explanation from ontological commitments that made it vulnerable, Fichte is able to readmit ontological assertions in so far as they are strictly extrapolated from the initially uncommitted perspective; the fact that ontological assertion is reached in this indirect way, rather than "dogmatically" assumed to be possible ab initio, is what crucially allows Fichte to claim that in his hands systematic philosophy avoids Spinozism and gives reality to freedom, and that his metaphysics are genuinely Critical. To this extent at least, Hegel's allegation that the WL amounts to a "whole nest' of thoughtless contradictions" with respect to its ontological commitments appears merely to reflect a failure to grasp the complexity of Fichte's position. ${ }^{88}$

There is a further element, of high importance, to be brought out in Fichte's account of the status of the WL. Consider the following, very clear statement of his:

The questions of whether the Wissenschaftslehre takes knowledge to be subjective or objective, and of whether it is idealism or realism, have no meaning; for these distinctions are first made within the W.L., not outside it, and not beforehand; and without the W.L. they remain unintelligible. ${ }^{89}$

This, I suggest, provides the final key to understanding Fichte's position regarding the Ontological/Non-Ontological issue. Fichte's position must be that, in all strictness, no prior and independent description can be given of the status of the WL's propositions: they cannot be qualified as "merely practical," "merely regulative," "mere postulates," and so on; these descriptions have at most heuristic value, in so far

\footnotetext{
${ }^{88}$ Hegel, 1807, p. 374 [HW III, 452].

${ }^{89}$ Fichte to Schelling, 31 May 1801 [GA III, 5: 45-6].
} 
as they help induct us into the system. And this means that the question which we have been pursuing must be cancelled: if the very distinction of ontological from nonontological status is generated only within the WL, then it can make no sense to characterise globally the transcendental conditions specified in the WL as reflecting either an Ontological or a Non-Ontological conception of philosophical explanation. This would explain Fichte's appearance of systematic ambiguity. And what Fichte means - in the fourth passage discussed in section 4.2, from the WL novo methodo lectures - by citing the WL's identification of "real existence" with "necessary thinking" in answer to the question whether the WL's transcendental grounds have ontological status, is simply that, in so far as our reflection on the acts postulated in the WL proceeds inside the WL, no gap can open up between the two, while from the external standpoint where the question is posed by such as Forberg, the distinction which the question presupposes has yet to be drawn. ${ }^{90}$ The answer to the earlier question of how we can conceive a unitary state of affairs incorporating an equivalence of "real existence" and "necessary thinking" thus lies in the selfenclosing circularity repeatedly claimed by Fichte as a distinguishing virtue of the WL: in order to separate intelligibly "real existence" and "necessary thinking" at the highest level of reflection, it would be necessary to break out of the WL's circle, which cannot be done. The question of whether or not, in talking of the positing of the absolute I, Fichte is also and thereby claiming "real existence" for the absolute I is accordingly dissolved, and merely reflects the distance that separates the transcendental from the ordinary and pre-Kantian standpoint, and the difficulty of articulating the former in terms that make sense to the latter. Finally, it is to be emphasised that the metaphilosophical structure just described, far from being itself a merely external, superadded gloss on the WL, is held to be immanent in pure "activity" - which is "higher than any being" in the sense of preceding the Ontological/Non-Ontological distinction.

Fichte's debate with Schelling and Hegel accordingly appears in the following light. In the first place, Fichte and Schelling cannot be opposed to one another, as is often claimed, in terms of respective adherence to Non-Ontological and Ontological conceptions of philosophical explanation. ${ }^{91}$ What separates them is a finer issue.

If Fichte's ultimate response to the question of Ontological/Non-Ontological status is, as suggested, that the distinction is properly internal to his system, then it is absolutely crucial that the system be truly "total," that it have no thinkable "outside:" for if scope does remain, after the philosophical construction of the WL is completed, for thought of "real existence" apart from "necessary thinking," then the question of Ontological/Non-Ontological status will not have been absorbed into Fichte's system - it will be possible to step outside the WL and ask about its status, and the WL will not be immune from the doubt that its philosophical explanations express a mere perspective on being.

\footnotetext{
90 This interpretation is corroborated by the important passage in Fichte, 1798a, pp. 22-3 [FW IV, 1618]. See also Fichte's rejection of Reinhold's suggestion that the WL needs to explain itself in independent, external terms: Fichte to Reinhold, 4 July 1797 [GA III, 3: 71] (Fichte 1988, p. 421).

${ }^{91}$ Nor can Schelling's philosophy be represented as a retrogressive departure from the properly transcendental project pursued in Fichte; see di Giovanni, 2005, p. 272.
} 
The claim of Schelling and Hegel is that, on account of the subjective bias of Fichte's fundamental principle, the WL's claim to totalisation fails: its identification of real existence with necessary thinking is made only from a certain angle, while what is needed is a non-compromised identification of thought and existence from "no" angle. This criticism, set out at length in Hegel's Differenz essay, is expressed succinctly in a letter of Schelling to Fichte:

in order to preserve your system, one must first decide to proceed from seeing [Sehen] and to end with the absolute (that which is truly speculative), roughly in the same way that, in Kant's philosophy, moral law must come first and God last for the system to remain in place. The necessity to proceed from seeing confines you and your philosophy to a thoroughly conditioned series in which nothing of the absolute remains to be met with. ${ }^{92}$

Schelling's point is that, even if it is granted that the ontologically uncommitted consciousness of the categorical imperative provides the correct model for conceiving consciousness or "Sehen" in general, and that the WL can be extrapolated from it, the (external) question arises how we are to think of this perspective. The question arises because Fichte's claim for the absoluteness of the practical, ontologically uncommitted perspective is premised on an original setting aside of the ontological order: practical consciousness defines itself against the order of being (on a merely "immediate" basis, in Hegel's language). The WL is thus premised on an original decision to take a non-ontological mode of consciousness, over and against ontologically-orientated consciousness, as our philosophical starting-point. To say this is not to disagree with Fichte, who acknowledges openly that a choice of startingpoint must be made but thinks that, for all of the powerful reasons given in the "First Introduction," the rationality of his, the idealist's, choice is beyond question. Still, even granting Fichte the argument of the "First Introduction," what remains undischarged is the premise expressing a choice which it seems we must think of as conditioning the WL's perspective. In relation to philosophical naturalism and other dogmatic alternatives to idealism (assuming the persuasiveness of the "First Introduction") this represents no weakness. But it does, arguably, leave Fichte's position open in principle to being improved upon: if it were possible to construct the system of philosophy in such a way that it could be regarded as encompassing at its very outset both Fichte's ontologically uncommitted consciousness and the ontological order, excluding neither for the sake of the other, then his position could be regarded as overtaken. ${ }^{93}$

On this critical issue - of whether the WL is truly limited in a way that leaves it open in principle to being superseded - Fichte of course has much to say: it is his claim that the WL expresses the highest degree of absoluteness available for finite

\footnotetext{
${ }^{92}$ Schelling to Fichte, 3 October 1801 [GA III, 5: 82].

${ }^{93}$ Schelling's alternative is to identify the transcendental with necessary being: what Fichte conceives as non-ontological perspective, on Schelling's account, is but an expression of this being. With this Schelling can also claim to have answered Schulze, since if transcendental explanation refers to something that exists necessarily, then its ontological commitments cannot be problematic.
} 
reason and that any putatively higher principle relapses into a pre-Kantian Ontological conception. ${ }^{94}$ Adjudicating Fichte's argument with Schelling and Hegel is extremely difficult, but for present purposes all that need be said is that it is doubtful that Fichte can supply a proof that any attempt to overtake the WL in the way described will be objectionably dogmatic, ${ }^{95}$ and to that extent the development of post-Fichtean German idealism is made intelligible in terms of the Ontological/Non-Ontological issue.

The endeavour in German idealism to provide a form of philosophical explanation that can claim to have internalised the Ontological/Non-Ontological distinction - to conceive transcendental grounds in a way which allows escape from vacillation between the two conceptions and avoids the objections to which each, when set in opposition to the other, is exposed - forms part of the German idealists' attempt to resolve traditional metaphysical problems by transcendental means and to unite realism and idealism. The issue emerges again and again: it can be shown to be involved in the German Romantics' criticism of and departure from the path taken by Fichte and Schelling; in Schelling's theory of absolute identity as an ontological/preontological point of indifference, and in his associated complex distinctions of being, existence and ground; in Hegel's chapter on the inverted world in the Phenomenology and his treatment of the concept of ground in the doctrine of essence; and it makes a final appearance in Schelling's late criticism of Hegel. ${ }^{96}$ Kant's ambiguity regarding the Ontological/Non-Ontological status of the transcendental is not quickly resolved but struggled over both within and between the German idealists' positions; a single protracted debate extends from Kant's Beweisgrund of 1762 to Schelling's

Abhandlung on the source of eternal truths of $1850 .{ }^{97}$ The incorporation of a NonOntological turn, and the further attempt to resolve the Ontological/Non-Ontological metaphilosophical antinomy, is also, I have suggested, an important part of what makes the transcendental grounding of the world in German idealism appear, in a way that pre-Kantian metaphysics does not, an image of reality turned inside out. ${ }^{98}$

\footnotetext{
${ }^{94}$ See e.g. Fichte to Schelling, 31 May 1801 [GA III, 5: 43-53] and Fichte, 1804, p. 30 [FW X, 101]. Fichte's claim to incorporate, in uniquely coherent form, Schelling's point of indifference is explicit in Fichte, 1804, Lecture 14.

${ }^{95}$ If Fichte supposes himself to have done so, this is because he mistakes Schelling's attempt to sublate the Ontological/Non-Ontological opposition for a "dogmatic," non-transcendental reassertion of the Ontological conception: see, e.g., Fichte's remarks on System of Transcendental Idealism [FW XI, 368-70], Fichte, 1804, p. 25 [FW X, 95], and Fichte, 1806, pp. 364, 366, 372.

${ }^{96}$ It is also resumed a century later in a different transcendental context, in the argument of Husserl and Heidegger. It is of interest that Heidegger tends to interpret Fichte Non-Ontologically (at one level at least) and regards Fichte's position as defective in respects which recall his criticisms of Husserl: see Heidegger, 1929, e.g., pp. 56 ff., 139, 248, 251, and 1936-38, §§103-4.

${ }^{97}$ Schelling 1850 , in which Schelling demonstrates the continuity of the Kantian issue with central questions of ancient and medieval philosophy.

${ }^{98}$ I am grateful to Peter Dews, Béatrice Han-Pile, Wayne Martin, Mark Sacks, Günther Zöller and others for valuable comments on an earlier draft of this paper presented at the Fichte Workshop as part of the Transcendental Philosophy and Naturalism project, and to the Arts and Humanities Research Council and the Philosophy Department of University College London for research leave that enabled its completion.
} 


\section{References}

\section{Primary sources}

References to Fichte's writings ["FW," followed by volume and page number] are to Johann Gottlieb Fichtes sämmtliche Werke, hrsg. Immanuel Hermann Fichte, 8 Bde. (Berlin: Veit \& Comp., 1845-46), and Johann Gottlieb Fichtes nachgelassene Werke, hrsg. Immanuel Hermann Fichte, 3 Bde. (Bonn: Adolph-Marcus, 1834-35); reprinted, 11 Bde., Berlin: Walter de Gruyter, 1971. References to writings not included in I. H. Fichte's edition are to J. G. Fichte: Gesamtausgabe der Bayerischen Akademie der Wissenschaften, hrsg. Reinhard Lauth, Hans Jacob, und Hans Gliwitzky, unter Mitarb. von Manfred Zahn, Richard Schottky, und Peter Schneider, Stuttgart-Bad Cannstatt: Frommann-Holzboog, 1964- [“GA," followed by series, volume, and page number].

References to Schelling's writings [“SW," followed by volume and page number] are to Schellings Werke. Nach der Originalausgabe in neuer Anordung, hrsg. Manfred Schröter (München: Beck, 1927-).

References to Hegel's writings ["HW," followed by volume and page number] are to Georg Wilhelm Friedrich Hegel: Werke. Auf der Grundlage der Werke von 1832-1845 neu edierte Ausgabe, hrsg. Eva Moldenhauer und Karl Markus Michel, Frankfurt am Main: Suhrkamp, 1979 (Theorie-Werkausgabe).

English translations are taken from the works listed below; in cases where the translation has been modified, this is noted. Where no published translation exists, translations are my own.

Fichte, Johann Gottlieb (1794a): "Review of Aenesidemus" ["Recension des Aenesidemus"], in: Fichte, 1988, pp. 53-77.

---- (1794b): Concerning the Difference between the Spirit and the Letter within Philosophy [Ueber den Unterschied des Geistes und des Buchstabens in der Philosophie, in GA II, 3: 315-42], in: Fichte, 1988, pp. 185-215. ---- (1794c): Concerning the Concept of the Wissenschaftslehre [Ueber den Begriff der Wissenschaftslehre oder der sogenannten Philosophie], in: Fichte, 1988, pp. 87135 .

---- (1794-95): Foundations of the Entire Science of Knowledge [Grundlage der gesammten Wissenschaftslehre], in: The Science of Knowledge, with the First and Second Introductions, ed. and trans. Peter Heath and John Lachs, Cambridge: Cambridge University Press, 1982, pp. 87-286.

----- (1795): Outline of the Distinctive Character of the Wissenschaftslehre with Respect to the Theoretical Faculty [Grundriss des Eigenthümlichen der Wissenschaftslehre, in Rücksicht auf das theoretische Vermögen, als Handschrift für seine Zuhörer], in: Fichte, 1988, pp. 233-306.

---- (1796): “A Comparison Between Prof. Schmid's System and the Wissenschaftslehre [Excerpt]" ["Vergleichung des vom Herrn Prof. Schmid aufgestellten Systems mit der Wissenschaftslehre"], in: Fichte, 1988, pp. 307-35. 
----- (1796-97): Foundations of Natural Right, According to the Principles of the Wissenschaftslehre [Grundlage des Naturrechts, nach Principien der Wissenschaftslehre], ed. Frederick Neuhouser, trans. Michael Baur, Cambridge: Cambridge University Press, 2000.

----- (1796/99): Foundations of Transcendental Philosophy: (Wissenschaftslehre) nova methodo (1796/99) [Wissenschaftslehre novo methodo, Halle und Krause

Kollegnachschriften], ed. and trans. Daniel Breazeale, Ithaca, NY: Cornell University Press, 1992. [WLnm = Wissenschaftslehre nova methodo. Kollegnachschrift K. Chr. Fr. Krause 1798/99, hrsg. Erich Fuchs, Hamburg: Meiner, 1982].

---- (1797a): "[First] Introduction to the Wissenschaftslehre" ["Erste Einleitung in die Wissenschaftslehre"], in: Fichte, 1994, pp. 2-35.

---- (1797b): "Second Introduction to the Wissenschaftslehre" ["Zweite Einleitung in die Wissenschaftslehre"], in: Fichte, 1994, pp. 36-105.

----- (1797c): Attempt at a New Presentation of the Wissenschaftslehre, Chapter One [Versuch einer neuen Darstellung der Wissenschaftslehre, Erstes Kapitel], in: Fichte, 1994, pp. 106-18.

---- (1798a): The System of Ethics According to the Principles of the

Wissenschaftslehre [Das System der Sittenlehre nach den Prinzipien der

Wissenschaftslehre], ed. Daniel Breazeale and Günther Zöller, Cambridge:

Cambridge University Press, 2005.

----- (1798b): "Postscript to the Preceding Article and Preface to the Following One" ["Nacherinnerung zu dem vorstehenden, und Vorerinnerung zu dem folgenden Aufsatze"], in: Fichte, 1994, pp. 133-40.

---- (1799): "The Religious Significance of the Science of Knowledge"

["Rückerinnerungen, Antworten, Fragen"], in: The Science of Knowledge, trans. A. E. Kroeger, Philadelphia: Lippincott, 1868, pp. 339-77.

---- (1800): The Vocation of Man [Die Bestimmung des Menschen], trans. Peter

Preuss, Indianapolis: Hackett, 1987.

---- (1801): A Crystal Clear Report to the General Public Concerning the Actual

Essence of the Newest Philosophy: An Attempt to Force the Reader to Understand

[Sonnenklarer Bericht an das größere Publikum über das eigentliche Wesen der neuesten Philosophie. Ein Versuch, die Leser zum Verstehen zu zwingen], trans. John Botterman and William Rasch, in: Philosophy of German Idealism: Fichte, Jacobi, and Schelling, ed. Ernst Behler, New York: Continuum, 1987.

---- (1804): The Science of Knowing: J. G. Fichte's 1804 Lectures on the Wissenschaftslehre [Die Wissenschaftslehre, Zweiter Vortrag im Jahre 1804], trans. Wayne Wright, Albany, N.Y.: State University of New York Press, 2005.

----- (1806): Bericht über den Begriff der Wissenschaftslehre und die bisherigen Schicksale derselben [FW VIII, 361-407].

---- (1988): Early Philosophical Writings, trans. and ed. Daniel Breazeale, Ithaca, N.Y.: Cornell University Press.

---- (1994): Introductions to the Wissenschaftslehre and Other Writings (1797-1800), trans. and ed. Daniel Breazeale, Indianapolis: Hackett, 1994. 
Forberg, Friedrich Karl (1797-98): Briefe über die neueste Philosophie, in: Martin Oesch, Hrsg., Aus der Frühzeit des deutschen Idealismus: Texte zur

Wissenschaftslehre Fichtes 1794-1804. Würzburg: Königshausen und Neumann, 1987, S. 153-81.

---- (1798): “Entwickelung des Begriffs der Religion,” Philosophisches Journal, Bd. 8, Heft 1, S. 21-46. Reprinted in: Hans Lindau, Hrsg., Die Schriften zu J. G. Fichtes Atheismus-Streit, München: Georg Müller, 1912, S. 37-58.

Hegel, Georg Wilhelm Friedrich (1802): Faith and Knowledge [Glauben und Wissen], trans. Walter Cerf and H. S. Harris, Albany, N.Y.: State University of New York Press, 1977.

---- (1807): Phenomenology of Spirit [Phänomenologie des Geistes], trans. A. V. Miller, Oxford: Oxford University Press, 1977.

Jacobi, Johann Friedrich (1785): Ueber die Lehre des Spinoza in Briefen an den Herrn Moses Mendelssohn, Breslau: Gottl. Löwe. Trans.: Concerning the Doctrine of Spinoza in Letters to Herr Moses Mendelssohn, in: The Main Philosophical Writings and the Novel "Allwill," trans. and ed. George di Giovanni, Montreal \& Kingston: McGill-Queen's University Press, pp. 173-251.

Maimon, Salomon (1794): Versuch einer neuen Logik oder Theorie des Denkens nebst angehängten Briefen des Philateles an Aenesidemus, Berlin: Ernst Felisch. Novalis (1795-96): Fichte-Studien, in: Paul Kluckhohn und Richard Samuel, Hrsg., Novalis Schriften: die Werke Friedrich von Hardenbergs, Bd. 2, Das philosophische Werk I, Abteilung II: Philosophische Studien 1795-96, Stuttgart: Kohlhammer, 1965. Trans. Fichte Studies, ed. Jane Kneller, Cambridge: Cambridge University Press, 2003.

Schad, Johann Baptist (1800): Gemeinfaßliche Darstellung des Fichteschen Systems und der daraus hervorgehenden Religionstheorie [Teildruck], in: Martin Oesch, Hrsg., Aus der Frühzeit des deutschen Idealismus: Texte zur Wissenschaftslehre Fichtes 1794-1804. Würzburg: Königshausen und Neumann, 1987, S. 113-38. Schelling, Friedrich Wilhelm Joseph von (1795): Philosophical Letters on Dogmatism and Criticism [Philosophische Briefe über Dogmatismus und Kritizismus], in: The Unconditional in Human Knowledge: Four Early Essays 17941796, ed. Fritz Marti, Lewisburg: Bucknell University Press, 1980, pp. 156-218. ---- (1797-98): Treatise Explicatory of the Idealism in the Science of Knowledge [Abhandlungen zur Erläuterung des Idealismus der Wissenschaftslehre, in: Idealism and the Endgame of Theory: Three Essays, trans. and ed. Thomas Pfau, Albany: State University of New York Press, 1994, pp. 61-138.

---- (1800): System of Transcendental Idealism [System des transzendentalen Idealismus], trans. Peter Heath, Charlottesville: University of Virginia, 1978. ---- (1802): Bruno, or On the Natural and the Divine Principle of Things, ed. and trans. Michael G. Vater, Albany, N.Y.: State University of New York Press, 1984. ---- (1850): "On the Source of the Eternal Truths" [Abhandlung über die Quelle der ewigen Wahrheiten], trans. Edward A. Beach, in: The Owl of Minerva, vol. 22, 1990, pp. 55-67. 
Schelling, Friedrich Wilhelm Joseph von, and Georg Wilhelm Friedrich Hegel (1802): "The Critical Journal, Introduction: On The Essence of Philosophical Criticism Generally, and its Relationship to the Present State of Philosophy" ["Einleitung. Über das Wesen der philosophischen Kritik überhaupt und ihr Verhältnis zum gegenwärtigen Zustand der Philosophie insbesondere"], trans. H. S. Harris, in: George di Giovanni and H. S. Harris, eds., Between Kant and Hegel: Texts in the Development of Post-Kantian Idealism, Indianapolis: Hackett, 2000, pp. 272 310.

Schulze, Gottlob Ernst (1792): Aenesidemus oder über die Fundamente der von dem Herrn Prof. Reinhold in Jena gelieferten Elementar-Philosophie, nebst einer Verteidigung gegen die Anmassungen der Vernunftkritik, Helmstädt. Trans. [Excerpt] Aenesidemus, Or Concerning the Foundations of the Philosophy of the Elements Issued by Prof. Reinhold in Jena Together with a Defence of Skepticism Against the Pretensions of The Critique of Reason, in: George di Giovanni and H. S. Harris, eds., Between Kant and Hegel: Texts in the Development of Post-Kantian Idealism, Indianapolis: Hackett, 2000, pp. 104-35.

\section{Secondary sources}

Beiser, Frederick C. (2002): German Idealism: The Struggle Against Subjectivism, 1781-1801, Cambridge, Mass.: Harvard University Press.

Bell, David (2001): "Is Empirical Realism Compatible with Transcendental Idealism?," in: Ralph Schumacher, Hrsg., Idealismus als Theorie der Repräsentation?, Paderborn: Menthis, S. 167-79.

Bourgeois, Bernard (1995): L'idéalisme de Fichte, Paris: Vrin.

Breazeale, Daniel (2002): "Fichte's Philosophical Fictions," in: Daniel Breazeale and Tom Rockmore, eds., New Essays on Fichte's Later Jena "Wissenschaftslehre," Evanston, Ill: Northwestern University Press, pp. 175-208.

Ferry, Luc (1990): Rights: The New Quarrel between the Ancients and the Moderns, trans. Franklin Philip, Chicago: University of Chicago Press.

di Giovanni, George (2005): Freedom and Religion in Kant and His Immediate Successors: The Vocation of Humankind, 1774-1800, Cambridge: Cambridge University Press.

Hartmann, Nicolai (1923): Die Philosophie des deutschen Idealismus, 1. Teil: Fichte, Schelling und die Romantik, Berlin: Walter de Gruyter.

Heidegger, Martin (1929): Der deutsche Idealismus (Fichte, Schelling, Hegel) und die philosophische Problemlage der Gegenwart, Gesamtausgabe II. Abt.: Vorlesungen 1919-44, Bd. 28, hrsg. Claudius Strube, Frankfurt am Main: Klostermann, 1997. Heidegger, Martin (1936-38): Contributions to Philosophy (From Enowning) [Beiträge zur Philosophie (Vom Ereignis)], trans. Parvis Emad and Kenneth Maly, Bloomington: Indiana University Press, 1999.

Heimsoeth, Heinz (1923): Fichte, München: Ernst Reinhardt. 
Kuehn, Manfred (1987): Scottish Common Sense in Germany, 1768-1800: A Contribution to the History of Critical Philosophy, Kingston, Ontario: McGillQueen's University Press.

Lachs, John (1987-88): “Is There an Absolute Self?," in: The Philosophical Forum, vol. 19, pp. 69-81.

Mandt, A. J. (1984): "Fichte's Idealism in Theory and Practice," in: Idealistic

Studies, vol. 14, pp. 127-47.

Martin, Gottfried (1968): General Metaphysics: Its Problems and its Method, trans. Daniel O’Connor, London: Allen \& Unwin.

Martin, Wayne (1997): Idealism and Objectivity: Understanding Fichte's Jena Project, Stanford, Calif.: Stanford University Press.

Moore, A. W. (1997): Points of View, Oxford: Clarendon.

Philonenko, Alexis (1966): La Liberté humaine dans la philosophie de Fichte, Paris: Vrin.

---- (1973): “Fichte," Histoire de la philosophie II, 2, ed. Y. Belaval, Paris:

Gallimard.

---- (1987-88): "Fichte and the Critique of Metaphysics," in: The Philosophical

Forum, vol. 19, pp. 124-39.

Sacks, Mark (1989): The World We Found: The Limits of Ontological Talk, London: Duckworth.

---- (2000): Objectivity and Insight, Oxford: Oxford University Press.

Vater, Michael (1994): “The Wissenschaftslehre of 1801-02," in: Daniel Breazeale and Tom Rockmore, eds., Fichte: Historical Contexts/Contemporary Controversies, New Jersey: Humanities Press, pp. 191-210.

Zöller, Günther (1998): Fichte's Transcendental Philosophy: The Original Duplicity Of Intelligence And Will, Cambridge: Cambridge University Press.

----- (2001): "Positing and Determining in Fichte's Foundation of the Entire

Wissenschaftslehre," in Daniel Breazeale and Tom Rockmore, eds., New Essays in Fichte's Foundation of the Entire Doctrine of Scientific Knowledge, New York:

Humanity Books, pp. 138-152. 